\title{
Grammar Translation Method (GTM) Versus Communicative Language Teaching (CLT); A Review of Literature
}

\author{
Muhammad Natsir (Corresponding author) \\ Department of English Language and Literature, Universitas Negeri Medan \\ E-mail: mnatsir0@gmail.com \\ Dedi Sanjaya \\ Department of English Language and Literature, Universitas Negeri Medan \\ College of Arts and Sciences, Universiti Utara Malaysia \\ E-mail: sanjayadedihasibuan@gmail.com
}

Received: 05-11- 2013

doi:10.7575/aiac.ijels.v.2n.1p.58
Accepted: 20-12-2013

URL: http://dx.doi.org/10.7575/aiac.ijels.v.2n.1p.58

Published: $31-01-2014$

\begin{abstract}
Methodology is one of the important elements to implement he objective of education in teaching learning process particularly in English classes. To give the information about two phenomenal methods namely GTM and CLT is the main purpose of this scientific writing since GTM is commonly used previously and CLT is very famous nowadays. In so doing, the strength of this paper is to improve the knowledge of educational practitioners especially in method of teaching English. The comparison between the two methods is elaborated clearly in terms of the principles. The principles are characteristic of teaching learning process, nature of instruction, handling the students' feelings and emotions, the role of native language of students, the language skills that are emphasized, and the way of teacher's response to students' errors. The more beneficial method nowadays is CLT but GTM also still has some positive things offer.
\end{abstract}

Keywords: Method of Teaching, Grammar Translation Method and Communicative Language Teaching.

\section{Introduction}

Teaching English as Second Language (ESL) or English as Foreign Language (EFL) is quite different with teaching first language $\left(\mathrm{L}_{1}\right)$. There are many elements that should be virtually known by the teacher to make teaching learning process an effective and efficient activity. One of the elements is Method. Anthony (1963) has given the definition of method for our purpose. A method to Language Teaching is a set of procedures or overall plan for systemic presentation to teach second or foreign language (Celce-Murcia, 2001:5;Brown, 2007:14). Hence, method is an extremely significant part in teaching ESL/EFL. Through an appropriate method, a teacher will make the students feel comfortable, pleased, and not bored. In so doing, the lesson's goals can be reached perfectly.

To realize that objective there are many methods that have appeared in field of teaching ESL and EFL. Structurally, from nine twentieth century there are nine of approaches that are integrated into many methods (Celce-Murcia, 2001:5) and interestingly, two of methods are Grammar Translation Method (GTM) and Communicative Language Teaching (CLT). Both of them are very interesting methods but they have the very obvious differences in terms of the approach and history of theory since GTM is a very classic method in contrast CLT is one of the latest methods that is used by teachers in many countries today in ESL/EFL classroom.

Principally, GTM is applied for helping students to read and appreciate foreign language literature objectives. In the other words, the essential aim of learning a language is to be able to read literature written in the target language. For a comparison, CLT intends largely to make the communicative competence become the main goal of language teaching process (Larsen-Freeman and Anderson, 2011:14 \&115). In asserting, through GTM the teacher gets the students to analyze the language rather than to use it. In contrast, through CLT the teacher has the students use the language rather than analyze it. Because of that, both of the methods are very interesting topics to discuss.

To discuss more about GTM and CLT, this paper is prepared to explore the comparison between both of methods. This paper is highly essential for teachers to know to what extent they are different, which one is more appropriate method for their students etc. To know more about both, the deep discussion about the comparison between GTM and CLT is provided in the next elaboration. 


\section{Comparison Between GTM and CLT}

The comparisons between GTM and CLT are very clear since the principle is very different. Therefore, they are provided in the table below so that the comparisons between the two methods we study will be easier to be understood.

Table. 1 The comparison between GTM and CLT

\begin{tabular}{|c|c|c|}
\hline Principle & $\begin{array}{c}\text { Grammar Translation Method } \\
\text { (GTM) }\end{array}$ & $\begin{array}{c}\text { Communicative Language } \\
\text { Teaching (CLT) }\end{array}$ \\
\hline \multirow[t]{7}{*}{$\begin{array}{l}\text { Characteristic of } \\
\text { Learning Process. }\end{array}$} & \multirow{7}{*}{$\begin{array}{l}\text { 1. Students are taught to } \\
\text { translate from native language } \\
\text { to the target language. } \\
\text { 2. Students learn grammar } \\
\text { deductively. } \\
\text { 3. Learners memorize native } \\
\text { language equivalents for the } \\
\text { target language vocabulary. }\end{array}$} & $\begin{array}{l}\text { 1. Everything is mostly done } \\
\text { with communicative intent. }\end{array}$ \\
\hline & & 2. Students use the language \\
\hline & & $\begin{array}{l}\text { through communicative } \\
\text { activities such as game and role- }\end{array}$ \\
\hline & & $\begin{array}{l}\text { plays. } \\
3 \text {. Communication is } \\
\text { purposeful. }\end{array}$ \\
\hline & & 4. Using authentic materials. \\
\hline & & $\begin{array}{l}\text { 5. Activities are often carried } \\
\text { out by students in small group. }\end{array}$ \\
\hline & & $\begin{array}{l}\text { 6. Grammar is taught } \\
\text { inductively. }\end{array}$ \\
\hline \multirow[t]{3}{*}{ Nature of Interaction. } & $\begin{array}{l}\text { 1. The interaction is mostly } \\
\text { from the teachers to the } \\
\text { students. }\end{array}$ & \multirow{3}{*}{$\begin{array}{l}\text { 1. Teacher is a facilitator. } \\
\text { 2. Teacher sometimes becomes } \\
\text { co-communicator. } \\
\text { 3. Students interact with one } \\
\text { another. }\end{array}$} \\
\hline & 2. Little students' initiation. & \\
\hline & $\begin{array}{l}\text { 3. Little student-student } \\
\text { interaction. }\end{array}$ & \\
\hline \multirow{3}{*}{$\begin{array}{l}\text { Handling the students' feeling } \\
\text { and emotion. }\end{array}$} & \multirow{3}{*}{$\begin{array}{l}\text { 1. There is no principle related } \\
\text { to this area. }\end{array}$} & 1. Motivate the students. \\
\hline & & $\begin{array}{l}\text { 2. Teacher gives the opportunity } \\
\text { to the students to express their } \\
\text { individuality. }\end{array}$ \\
\hline & & $\begin{array}{l}\text { 3. Students security is } \\
\text { enhanced by cooperative } \\
\text { interaction. }\end{array}$ \\
\hline
\end{tabular}

\begin{tabular}{ll}
\hline The role of native language of & 1 . The meaning of the target \\
students. & language is made clear by \\
& translating into the learners' \\
& native language.
\end{tabular}

2 . The native language is mostly used in teaching learning process.
1. Students' native language is permitted.

2. Most of the activities are explained by using target language and native language only for certain thing.

1. The functions are
reintroduced and the more complex forms are learned.

2. Students work on all four skills (listening, reading, writing and speaking) from the beginning.

\begin{tabular}{lll}
\hline The way of teachers' response & $\begin{array}{l}\text { 1. Correct answer is extremely } \\
\text { significant. }\end{array}$ \\
to students' error. & $\begin{array}{l}\text { 1. Error of form is tolerated } \\
\text { during the fluency-based }\end{array}$ \\
& $\begin{array}{ll}\text { 2. If students makes an error the activities. } \\
\text { teacher will supply them with } \\
\text { the correct answer. }\end{array}$ & $\begin{array}{l}\text { 2. The teacher may note the } \\
\text { learners error and return to the } \\
\text { learners with accuracy-based } \\
\text { activities. }\end{array}$
\end{tabular}




\section{Discussion}

\subsection{Characteristic of Teaching Learning Process}

From both GTM and CLT characteristics of teaching learning process, there are five of elements that are very contrasting between both of methods. The first one is mother tongue that in GTM, the students are taught by using the mother tongue. It means that the teacher facilitates students in teaching learning process of target language uses the native language. Additionally, Harmer (2007:63) said that whatever the teachers teach and the students learn about the target language, they reflect the target language to their mother tongue and vice versa. In comparison, CLT actually uses the native language in teaching learning process but in certain word (Brown, 2007:49). Mother tongue is not allowed for all the communications in teaching learning process. The teacher facilitates the students to get the target language by using the target language as the tool of interaction and communication. Secondly, the vocabulary in GTM is memorized by translating it to the native language. This way is used to make the students know the relevant meaning and useful in the target language (brown, 2007:19). In another way, CLT method gives the instruction to the students to acquire the vocabulary of target language by not using the native language as the reflection. Furthermore, the teacher instructs the students to acquire the vocabulary through real world contexts (Brown, 2007:46). One example is by using real picture, realia or the implementation of the word in sentence or expression. Thirdly, in terms of the grammar, GTM method emphasizes that learners must understand the grammar before producing the sentence of text. In the other word, the students are taught the grammar deductively (Harmer, 2007:63. Larsen-Freeman, 2011:18. Brown, 2007:19). The students will produce the sentence systematically, no variation, and very rigid. Additionally, based on the observation on some teaching learning process in Indonesia on October 16-17 2013, the students are afraid to speak English in daily life because they do not often to use the language for communication. They have a hesitation on their pronunciation and may be on the dialect that they have in the native language gives an influence on their target language. This approach is very different with CLT since CLT method emphasizes the teacher teach grammar inductively or through retrospective approach (Thomspson, 1996). Furthermore, this CLT encourages the students to communicate with target language without focusing on grammar first (Larsen-Freeman, 2011:115. Hiep: 2005:4)). In so doing, they focus on the students' willingness to communicate with the target language and check or revise the students' grammar after producing the language, for example in sentence or text. This way will make the students enjoy the lesson, and they do not hesitate and are not shy to produce the language. It is same with how they acquire the first language or mother tongue. But one of the problems is that they will get the error in grammar if the teacher is not able to teach grammar at the end of the lesson. The next is about the material. In GTM method there is no instruction using the authentic material. All the materials are from the teacher or a systematic book. The material is already settled by the teacher. In this case, the learners do not get familiar with the social language and when they are asked to use or realize their knowledge to the social or daily context, they do not have the capability to do it. But one of the positive things from this side is the bad thing from out side of the classroom does not enter to the students' mind. So they are awaked from the bad attitude that the authentic material brings from outside of class. In comparison, the CLT Method usually uses the authentic material to make the students familiar and understand the real context of the subject given (Hiep, 2005:5). Additionally, Wong, Kwok and Choi in Xerri (2012:43) stated that it is very beneficial for students because at the end of the learning process they will join with the social life and they need the real context to be one of the social member lives. But in this side the teacher has to filter the material carefully so the inappropriate thing does not enter to the students' mind or attitude. The last but not least is the purpose of the study. In GTM method the students are not forced to communicate in the target language but in CLT method the students are emphasized to communicate in target language for the daily and teaching learning activities. On the other hand, GTM method gets the students to analyze the language rather than to use the language (Celce-Murcia, 2001:6). In contrast, the CLT method has the students use the language rather than analyze the language (Larsen-Freeman, 2011: 115). Additionally, the goal of our language learning process is to enhance the students' ability to communicate in the target language.

\subsection{Nature of Interaction}

\subsubsection{Teacher - student interaction}

GTM Method is one-way interaction. Most of the activities in teaching learning process are coming from the teacher (Brown, 2007:19. Harmer, 2007:63). In other words, in this method the teacher is the main resource for teaching and learning and teacher demonstrates the material with one-way. The students just give the question to the teacher if they do not understand the meaning of words and if they do not understand the form of the sentence given. In so doing, the teacher will give the answer directly to make the students understand the lesson. Contrastively, in CLT method the there is an active interaction between the teacher and the students. The teacher considers the students as friends to discuss the topic. Hence, the teacher is not only the main source but also learners' friend to get to the goal of teaching learning process. So, in CLT there is an interaction from the teacher to students and from the students to the teacher actively (Thompson, 1996. Brown, 2007:47. Hiep, 2005:4).

\subsubsection{Student - student interaction}

From the previous data, in GTM method there is little interaction between students and mostly they never make an interaction in teaching learning process. Consequently, the students never communicate about the lesson and their knowledge is merely from the teacher. But in CLT method the interaction among the students is emphasized (Hiep, 2005:4), and they can communicate to solve the problem and to answer the question given by the teacher. This way is very good for the learning process as the teacher can be the co-communicator among the students so that the teaching learning processes become effective and efficient to get the goal of teaching learning process itself. 


\subsection{Handling the Students' Feeling and Emotion}

GTM method is very classical and the teacher does not care with the students' feeling and emotion because in this method there is no principle related to handling this area. Because of that, the relationship between teacher and the students is not so close since the students consider the teacher as something that is extremely formal, cannot be invited for fun or joking. In other word, there is a big distance between the teacher and students. In contrast, CLT is one of the modern methods in which the students and the teacher are considered partner in learning. In so doing, the students feel comfortable with the teacher since the students are given the opportunity to express their idea, hobby, and feeling. Additionally, as evidence from one of observations in CLT classroom, they are diligent to study because in this method the students are motivated by the teacher to get the objective (Brown, 2007:49). Furthermore, because in this method there is a good cooperation between the teacher and the students, the security of the students is enhanced so that the students can learn conveniently, focus and happily. All in all, in this case the CLT more care than GTM.

\subsection{The Role of Native Language of Students}

In GTM the role of native language is very important because it uses native language or $\mathrm{L}_{1}$ to understand the target language. Surprisingly, whatever the learners learn about the target language they will reflect it to their native language (Celce-Murcia, 2001:6. Brown, 2007:19. Harmer, 2007:63). Furthermore, while studying about grammar, the teachers and the students try to understand the grammar by using the native language. The teacher explores the grammar of target language by using native language and most of the teaching learning processes is done by using the native language as well. To compare, in CLT Method is actually using the native language but in certain word i.e. to emphasize the word, to know the meaning of the word since it is not familiar word, and to make joke and etcetera. Normally, all the teaching leaning process is acted by using target language (Thompson, 1996. Harmer, 2007:69. Brown, 2007:46-47). Hence, the goal of this method is to familiarize the students with the target language as well so that they can communicate contextually and well.

\subsection{The Language Skill that are Emphasized}

There are four skills that have to be mastered by the learners in language competence and performance. They are listening, reading, speaking and writing. As information, listening and reading are receptive skills. Then, speaking and writing are productive skills (Harmer, 2007: 270 and 275).

In GTM method, the skills that are emphasized are reading and writing. It means that the students merely get one skill how to get the information and one skill how to produce and deliver the information. Therefore, this method is not appropriate to enhance the students' ability in language learning especially in second/foreign language learning. When the students are only taught to get reading and writing skills, they will focus on vocabulary and grammar so that they do not get familiar with the other elements such as pronunciation, phonology, and real context of language use. Actually, this method expects the students to learn the rule of language in class and then the students perform it in daily life but until now it has not occurred in students daily life; even the students are afraid and shy to use the language incorrectly.

Contrastively, in CLT method the four skills are taught to the students from the beginning of teaching learning process. Normally, the students are divided into small groups and they get the four skills through their groups and classes. In this method, they get the competence and the performance completely since they use the language in their class and influence their daily life to use the language even though there are many mistakes. All in all, in CLT method the teacher teaches skills to the students more completely than in GTM methods.

\subsection{The Way Teacher Responds to Students Error}

In GTM method, accuracy is considered to be a necessity (Harmer, 2007:63). The teacher will directly revise the students' errors. Actually, this way might be good because the students know their mistakes directly but it affects the students confidence to produce the language because they are afraid they make mistake in classes. Furthermore, the students are extremely careful about their performance and they know how to analyze the language but they do not have ability and confidence to perform the language particularly in communicative performance.

On the other side, CLT method is a very humble method since in this method, the teacher permits the students' error but the teacher will guide the students to analyze and revise their errors (Brown, 2007:47). Beneficially, the students feel comfortable and happy to use the language and they do not lack confidence and are not shy to perform the language in their daily life. To sum up, both of CLT and GTM methods respond to the students in different ways, GTM is directly and CLT is indirectly. Both of the ways have their own advantages and disadvantages.

\section{Conclusion}

All in all, both of GTM and CLT methods are familiar for the teachers. In some of countries GTM is still applied even though it is an old method if we compare it with CLT method. The teacher has to know the suitable method for their teaching learning process as the condition, context and social culture in each of the countries is different. From the previous explanation about the comparison between CLT and GTM method, it can be stated that CLT is more communicative and cooperative than GTM enhancing students' abilities to use language since GTM is monotonous and includes a one-way transmission. The teacher is the main source of teaching learning process. In contrast, the CLT has many techniques in teaching learning process that makes students happy, comfortable, and interested in the lesson. And the teacher is not only the main source but he/she also can be a facilitator and co-communicator for students. 


\section{Reference}

Brown, H. D. (2007). Teaching by Principle; An Interactive Approach to Language Pedagogy. Third Edition. New York: Pearson Longman.

Celce-Murcia, M. (2001). Teaching English as a Second or Foreign Language. Third Edition. Heinle: Language Learning.

Harmer, J. (2007). The Practice of English Language Teaching. Fourth Edition. Cambridge: Pearson Longman.

Hiep, P.H. (2005). "Imported" Communicative Language Teaching Implications for Local Teachers. Journal of English Teaching Forum. 43 (4) 2-9.

Larsen-Freeman, D and Anderson, M. (2011). Techniques \& Priciples in Language Teaching. Oxford: Oxford University Press.

Thompson, G. (1996). Some Misconceptions about Communicative Language Teaching. ELT Journal. 50 (1) 9-15.

Xerri, D. (2012). The Use of Authentic Text with Postgraduate Students. Journal of Education an 